\title{
The Therapeutic Effects of Vitamin $C$ on Changes of Some Biochemical Parameters in Male Albino Rats Treated with Mixture of Food Additives (Sodium Benzoate + Mono Sodium glutamate + Chlorophyllin)
}

Eman G.E. Helal ${ }^{1 *}$, Mohamed A. Abdelaziz ${ }^{2}$, Hewaida A.E. Fadel ${ }^{3}$, Nahla S.A. EL-Shenawe ${ }^{1}$

${ }^{1}$ Department of Zoology, Faculty of Science (Girls), Al-Azhar University; ${ }^{2}$ Department of Physiology,

Faculty of Medicine,(Boys), Al-Azhar University; ${ }^{3}$ Department of Physiology and Ntritional Chemistry, National Nutrition Institute, Egypt

*Corresponding Author: Eman Helal, Email: emanhelal @ azhar.edu.eg, Mobile: 00201001025364, orcid.org/0000-0003-0527-7028

\begin{abstract}
Background: Food additives are substances intentionally added to food to change its characteristics, maintain and improve safety, maintain the nutrient value and to improve taste, texture, and appearance.

Aim of the work: This study aimed to determine the therapeutic effects of vitamin $\mathrm{C}$ against the hazardous effects of sodium benzoate, chlorophyllin and monosodium glutamate on some physiological parameters in male albino rats. Materials and Methods: this study had been done on thirty male albino rats with an average body weight 120-140 g. The animals were divided into three groups. Group 1: control, Group 2: rats treated with mixture sodium benzoate, chlorophyllin and monosodium glutamate and Group 3: rats treated with food additives mixture and vitamin C. Blood samples were collected and the separated sera were used for estimation of some biochemical parameters (liver enzymes, kidney functions, glucose, protein profile and lipid profile) and hormonal levels [testosterone, triiodothyronine (T3) and thyroxine (T4)].

Results: The biochemical results showed an increase in levels of fasting glucose, insulin, HOMA-IR, activities of AST and ALT, urea, creatinine, total cholesterol (TC), triglycerides (TG), LDL-C, VLDL, ratios of TC/HDL-C and LDL-C/HDL-C (risk factors) in mixture group accomphined by a significant decrease in protein profile (total protein, albumin and globulin), HDL-and testosterone hormone levels . On the other hand, these results turned back nearly to normal values after receiving vitamin $\mathrm{C}$.

Conclusion: The present study revealed capability of vitamin $\mathrm{C}$ to fight the grievous effects of food additives mixture on major physiological parameters.
\end{abstract}

Keywords: food additives, sodium benzoate (SB), Chlorophyllin(CHL), monosodium glutamate (MSG), Vitamin C (VIT. C).

\section{INTRODUCTION}

Monosodium glutamate (MSG) is a common example of one of the chemicals used in our modern foods. It is sodium salt for glutamic acids. Glutamate is one of the most common amino acids in nature and is the main component of many proteins and peptides in most tissues. Monosodium glutamate contains 78\% glutamic acid, $22 \%$ sodium and water. If large amounts of glutamate are taken, the levels of glutamate will increase in the portal circulation, which increases the metabolism of the glutamate, leading to the release of glucose, lactate, glutamine and other amino acids in the systemic blood circulation. Glutamic acid turns into alanine in the intestinal mucosa and lactate in the liver.

Glutamic acid is absorbed from the intestine by the active transport system of amino acids. Monosodium glutamate, which changes the metabolic rate of glucose use and low antioxidant defenses. It produces neurotoxicity, obesity and visual impairment. ${ }^{(\mathbf{1})}$.

Chlorophyllin is a derivative of sodium chloride and copper chlorophyll, where the central magnesium nucleus is replaced with other metals such as copper, iron or cobalt and methyl ether groups are replaced with sodium or potassium to convert into water.

Despite the industrial chemical changes that occur in chlorophyllin, this continues to provide the same functional properties of chlorophyll, a product found in various sources such as fruits, and vegetables because of its more stable production compared to chlorophyll. Chlorophyllin has been widely used as a food additive, accelerating healing, in the treatment of calcium oxalate kidney stones, in body control, urinary and fecal odors for patients with aging ${ }^{(2)}$.

Sodium benzoate is a common preservative used in many foods including salads, soft drinks, jams, fruit juices as well as pharmaceuticals to keep liquid medicines.

This compound is widely consumed indirectly by this compound, which has been reported to cause serious adverse effects in the body as a food additive. Benzoate is metabolized in the liver by association with glycine, leading to the formation of hyboric acid. The use of glycine in detoxification of benzoate leads to depletion in the level of glycine in the body, which can affect the metabolism of glycine involved. Low levels of glycine in the body can lead to lower levels of creatinine, glutamine, urea and uric 
acid $^{(3)}$. Ascorbic acid (AA) or vitamin $\mathrm{C}$ is a water soluble vitamin. In humans its deficiency has been associated with a wide spectrum of clinical manifestations such as scurvy, which is a lethal condition unless appropriately treated. The antioxidant role of AA in maintaining motor abilities has been well documented. It has been shown that AA elicits its antioxidant effect through donation of electrons and protection of other compounds from oxidation. In this process, vitamin $\mathrm{C}$ itself is oxidized but unreactive, and therefore ascorbic acid has been described as a good free radical scavenger. Several studies in human have demonstrated the effects of vitamin $\mathrm{C}$ on intestinal iron absorption, reduction of harmful oxidants in the stomach and vascular responsiveness. These effects have been reported to be mediated by the antioxidant actions of vitamin $\mathrm{C}$, which may play a role in iron absorption, gastric cancer prevention, vascular disease and hypertension. Vitamin $\mathrm{C}$ can also protect and stimulate biosynthesis of endothelial nitric oxide (NO), which is important for vascular relaxation. Vitamin $\mathrm{C}$ appears to have beneficial effects on erectile and testicular functions in healthy and unhealthy subjects with reproductive problems. Some evidence suggests that erectile and testicular dysfunction is associated with low plasma vitamin C concentrations ${ }^{(4)}$.

Therefore, this study aimed to study the effects of a mixture of different types of food additives (MSG, SB and CHL) on some biochemical parameters of male white mice. Besides, the effect of vitamin $\mathrm{C}$ as an antimicrobial for these compounds and whether it is able to improve these parameters and improve the toxicity caused by MSG and SB.

\section{MATERIALS AND METHODS}

Thirty male albino rats (weighing 120-140 g) were used in this study. Animals were housed in stainless steel cages, fed on rat chew and offered water ad libidum. Animals were divided into three equal groups (10 rats/each). The first group, the control untreated group, the second group, rats were orally administered with a mixture of food additives: sodium benzoate $(5 \mathrm{mg} / \mathrm{kg}$ b.wt./day), Chlorophyllin (15 $\mathrm{mg} / \mathrm{kgb} . w t . /$ day) and monosodium glutamate (15 $\mathrm{mg} / \mathrm{kg} \mathrm{b.wt}$./day) and the third group, rats were orally administrated with the previous mixture of food additives in addition to a dose of vitamin $\mathrm{C}(7 \mathrm{mg} / \mathrm{kg}$ b.wt./day). Body weights were recorded every week. After 30 days of treatment, animals were weighed and then decapitated after they were anesthetized with inhalation anesthesia using alcohol, chloroform, and ether in a ratio of 1:2:3 ${ }^{(5)}$. Blood samples were collected and centrifuged for 10 minutes at $5000 \mathrm{rpm}$ and sera were separated for analysis of biochemical parameters without storage or delay.

\section{Biochemical investigations:}

In the present study, total protein (TP) and albumin concentration were estimated, then serum globulin concentrations were calculated according to the formula ${ }^{(6)}$ :

\section{Globulin $(\mathrm{g} / \mathrm{dl})=$ total protein $(\mathrm{g} / \mathrm{dl})-$ albumin $(\mathrm{g} / \mathrm{dl})$}

Aspartate aminotransferase (AST), alanine aminotransferase (ALT) activities, creatinine, urea, fasting blood glucose concentrations as well as lipid profile including total cholesterol, triglycerides LDL$\mathrm{C}$ and HDL-C were also determined. All parameters were estimated using BioMerieux SA kits, France. Testosterone and thyroid hormones (T3 and T4) rapidly using (Biovendor Research and Diagnostic product reff).

Ratio of serum albumin/ globulin was determined. However, ratios of TC/HDL (risk factor 1) and LDL/HDL (risk factor 2) were also calculated after calculation of serum LDL-C (low-density lipoprotein cholesterol) and VLDL (very low-density lipoprotein cholesterol) using the Friedwald's ${ }^{(7)}$ and Norbert ${ }^{(8)}$ formulas, respectively as following:

Friedewald's ${ }^{(7)}$ equation: LDL $(\mathrm{mg} / \mathrm{dl})=\mathrm{TC}-\{\mathrm{HDL}$ $+[$ TG/5] $\}$.

Norbert ${ }^{(8)}$ equation: VLDL $=$ TG/5

\section{Determination of serum insulin level and HOMA- IR:}

By using an ELISA (Enzyme Linked Immunosorbent Assay) kit (U.E Type) for measurement of rat insulin with high sensitivity rapidly using (Biovendor Research and Diagnostic product reff) ${ }^{(9)}$.

\section{HOMA-IR:}

The approximating equation for insulin resistance, in the early model, used a fasting plasma glucose sample. Then it was calculated using insulinglucose product divided by a constant as follows:

HOMA -IR = fasting glucose $\mathrm{mg} / \mathrm{dl} \times$ Insulin $\mu \mathrm{u} / \mathrm{L} / 405$. Fasting glucose in mass units $\mathrm{mg} / \mathrm{dl}$.

IR is insulin resistance. Insulin is given in $\mu \mathrm{u} / \mathrm{L}^{(\mathbf{1 0})}$.

This study was conducted in accordance with ethical procedures and policies approved by Animal Care and Use Committee of Faculty of Science, AlAzhar University, Cairo, Egypt. The study was approved by the Ethics Board of Al-Azhar University.

\section{Statistical analysis}

The results were expressed as Mean \pm SE. Data were analyzed by t-test and were performed using the Statistical Package for Social Sciences (SPSS) program, version 20. The Bonferroni test was used as 
a method to compare significance between groups. The significance level was accepted at p-value $<0.05$.

\section{RESULTS}

Body weight: insignificant change was noticed in the percentage of body weight changes in all treated groups (Table 1).

\section{Glucose level:}

There was a highly significant increase $(p<0.01)$ in glucose, insulin value and HOMA-IR ratio in the mixture group in comparison with control rats. While in the group of (mixture + VIT.C), there was insignificant change as compared to control rats (Table 1).

Table (1): Percentage of body weight change, glucose level, insulin and HOMA-IR in control, Mixture (Sodium Benzoate+ Mono Sodium glutamate + Chlorophyllin)- and (Mixture+ Vitamin C)- treated animals

\begin{tabular}{|c|c|c|c|}
\hline Groups & control & Mixture & $\begin{array}{l}\text { Mixture } \\
+ \text { Vitamin C }\end{array}$ \\
\hline $\begin{array}{ll}\% \text { of } & \text { body } \\
\text { weight } & \\
\text { change from } \\
\text { basal levels }\end{array}$ & $\begin{array}{l}35.78 \pm \\
0.81\end{array}$ & $\begin{array}{l}37.41 \pm \\
0.77\end{array}$ & $\begin{array}{l}37.37 \pm \\
0.85\end{array}$ \\
\hline $\begin{array}{l}\% \text { of change } \\
\text { from control }\end{array}$ & & $4 \%$ & $4 \%$ \\
\hline Glucose $(\mathrm{mg} / \mathrm{dl})$ & $\begin{array}{l}75.41 \pm \\
2.21\end{array}$ & $\begin{array}{l}92.25 \pm \\
0.89 * *\end{array}$ & $\begin{array}{l}78.41 \pm \\
2.11\end{array}$ \\
\hline $\begin{array}{l}\% \text { of change } \\
\text { from control }\end{array}$ & & $22 \%$ & $4 \%$ \\
\hline INS $(\mu \mathrm{g} / \mathrm{dl})$ & $\begin{array}{l}4.04 \pm \\
0.37\end{array}$ & $\begin{array}{l}5.74 \pm \\
0.16^{* *}\end{array}$ & $4.66 \pm 0.24$ \\
\hline $\begin{array}{l}\% \text { of change } \\
\text { from control }\end{array}$ & & $42 \%$ & $15 \%$ \\
\hline HOM-IR & \begin{tabular}{|l|}
$0.74 \pm$ \\
0.07 \\
\end{tabular} & $\begin{array}{l}1.30 \pm \\
0.04 * *\end{array}$ & $0.89 \pm 0.04$ \\
\hline $\begin{array}{l}\% \text { of change } \\
\text { from control }\end{array}$ & & $76 \%$ & $20 \%$ \\
\hline
\end{tabular}

Values represent mean $\pm \mathrm{SE}$ (standard error).

$\mathrm{P}^{*}<0.05, \mathrm{P}^{* *}<0.01$ as compared to control group.

\section{Protein profile:}

The present study showed that there was a highly significant decrease in total protein and albumin $(\mathrm{p}<$ $0.01)$ while globulin recorded significant decrease $(\mathrm{p}<$ $0.05)$.

On the other hand, albumin/globulin ratio recorded insignificant change when compared to control group. VIT. C caused no significant change in previous parameters when compared to control group (Table 2).
Table (2): Serum total protein (g/dl), albumin (g/dl), globulin and albumin globulin ratio in control, Mixture (Sodium Benzoate + Mono Sodium glutamate + Chlorophyllin)- and (Mixture + Vitamin C)- treated animals

\begin{tabular}{|l|l|l|l|}
\hline Groups & Control & Mixture & $\begin{array}{l}\text { Mixture } \\
+ \text { Vitamin C }\end{array}$ \\
\hline Total Protein(g/dl) & $\begin{array}{l}6.66 \pm \\
0.34\end{array}$ & $\begin{array}{l}4.18 \pm \\
0.09 * *\end{array}$ & $6.25 \pm 0.10$ \\
\hline $\begin{array}{l}\text { \%of change from } \\
\text { control }\end{array}$ & & $-37 \%$ & $-6 \%$ \\
\hline Albumin(g/dl) & $\begin{array}{l}3.82 \pm \\
0.25\end{array}$ & $\begin{array}{l}2.20 \pm \\
0.11 * *\end{array}$ & $3.24 \pm 0.15$ \\
\hline $\begin{array}{l}\text { \%of change from } \\
\text { control }\end{array}$ & & $-42 \%$ & $-15 \%$ \\
\hline $\begin{array}{l}\text { Globulin (g/dl) } \\
\text { \%of change from } \\
\text { control }\end{array}$ & 0.25 & $\begin{array}{l}1.97 \pm \\
0.16 *\end{array}$ & $3.01 \pm 0.25$ \\
\hline $\begin{array}{l}\text { Albumin/Globulin } \\
\text { \% of change from }\end{array}$ & $\begin{array}{l}-30 \% \\
\text { control }\end{array}$ & $\begin{array}{l}1.15 \pm \\
0.12\end{array}$ & $6 \%$ \\
\hline
\end{tabular}

Values represent mean \pm SE (standard error).

( $\mathrm{P}^{*}<0.05, \mathrm{P}^{* *}<0.01$ as compared to control group).

\section{Liver functions:}

There was a highly significant increase $(p<0.001)$ in ALAT and ASAT activities in mixture-treated animals. VIT.C-treated group recorded a significant increase $(\mathrm{p}<0.05)$ in ALAT and insignificant change in ASAT as compared to control group (Table 3).

Table (3): ALAT and ASAT activities in control, Mixture (Sodium Benzoate + Mono Sodium glutamate + Chlorophyllin)- and (Mixture + Vitamin C)- treated animals

\begin{tabular}{|l|l|l|l|}
\hline Groups & Control & Mixture & $\begin{array}{l}\text { Mixture } \\
+ \text { Vitamin C }\end{array}$ \\
\hline ALAT (U/l) & $\begin{array}{l}22.98 \pm \\
1.69\end{array}$ & $46.70 \pm 1 * *$ & $\begin{array}{l}29.89 \pm \\
2.24 *\end{array}$ \\
\hline $\begin{array}{l}\text { \% of change } \\
\text { from control }\end{array}$ & & $103 \%$ & $30 \%$ \\
\hline ASAT (U/l) & $51.71 \pm$ & $72.32 \pm$ & $\begin{array}{l}54.35 \pm \\
1.45\end{array}$ \\
\hline $\begin{array}{l}\text { \% of change } \\
\text { from control }\end{array}$ & & $0.76^{* *}$ & $5 \%$ \\
\hline
\end{tabular}

Values represent mean $\pm \mathrm{SE}$ (standard error). $\left(\mathrm{P}^{*}<0.05, \mathrm{P}^{* *<}\right.$ 0.01 as compared to control group).

\section{Lipid profile:}

The animals that received a mixture of food additives (group 2) had a highly significant increase in all the parameters of lipid profile $(p<0.01)$, except HDL-C level that showed a highly significant decrease 
( $p<0.01)$ in comparison with control group. On the other hand, VIT. C-treated rats ameliorated all these parameters of lipid profile, except total cholesterol where there was a significant increase $(p<0.05)$ as compared to control rats (Table 4).

Table (4): Changes in total cholesterol (TC), triglyceride (TG), HDL-C, LDL-C, vLDL-C, LDL/HDL ratio and TC/HDL ratio in control, Mixture (Sodium Benzoate+ Mono Sodium glutamate + Chlorophyllin)- and (Mixture+ Vitamin C)-treated animals

\begin{tabular}{|c|c|c|c|}
\hline Groups & Control & Mixture & $\begin{array}{l}\text { Mixture } \\
\text { +Vitamin } \\
\text { C }\end{array}$ \\
\hline $\begin{array}{l}\text { Total } \\
\text { Cholesterol(mg/dl) }\end{array}$ & $\begin{array}{l}80.00 \pm \\
1.55\end{array}$ & $\begin{array}{l}100.41 \\
\pm \\
0.80 * *\end{array}$ & $\begin{array}{l}86.69 \pm \\
2.33^{*}\end{array}$ \\
\hline $\begin{array}{l}\text { \%of change from } \\
\text { control }\end{array}$ & & $26 \%$ & $8 \%$ \\
\hline Triglycerides $(\mathrm{mg} / \mathrm{dl})$ & $\begin{array}{l}75.78 \pm \\
1.96\end{array}$ & $\begin{array}{l}109.72 \\
\pm \\
1.76^{* *} \\
\end{array}$ & $\begin{array}{l}81.52 \pm \\
1.91\end{array}$ \\
\hline $\begin{array}{l}\text { \%of change from } \\
\text { control }\end{array}$ & & $45 \%$ & $8 \%$ \\
\hline HDL-C (mg/dl) & $\begin{array}{l}43.75 \pm \\
1.53 \\
\end{array}$ & $\begin{array}{l}31.96 \pm \\
1.07 * * \\
\end{array}$ & $\begin{array}{l}43.74 \pm \\
1.40\end{array}$ \\
\hline $\begin{array}{l}\text { \%of change from } \\
\text { control }\end{array}$ & & $-27 \%$ & $-1 \%$ \\
\hline LDL-C (mg/dl) & $\begin{array}{l}21.09 \pm \\
1.89\end{array}$ & $\begin{array}{l}46.51 \pm \\
1.47 * *\end{array}$ & $\begin{array}{l}26.65 \pm \\
3.97\end{array}$ \\
\hline $\begin{array}{l}\text { \%of change from } \\
\text { control }\end{array}$ & & $121 \%$ & $26 \%$ \\
\hline vLDL (mg/dl) & $\begin{array}{l}15.15 \pm \\
0.39\end{array}$ & $\begin{array}{l}21.94 \pm \\
0.35^{* *}\end{array}$ & $\begin{array}{l}16.30 \pm \\
0.38\end{array}$ \\
\hline $\begin{array}{l}\text { \%of change from } \\
\text { control }\end{array}$ & & $45 \%$ & $8 \%$ \\
\hline LDL/HDL & $\begin{array}{l}0.48 \pm \\
0.05\end{array}$ & $\begin{array}{l}1.46 \pm \\
0.09 * *\end{array}$ & $\begin{array}{l}0.61 \pm \\
0.11\end{array}$ \\
\hline $\begin{array}{l}\text { \%of change from } \\
\text { control }\end{array}$ & & $204 \%$ & $27 \%$ \\
\hline TC/HDL & $\begin{array}{l}1.83 \pm \\
0.06\end{array}$ & $\begin{array}{l}3.15 \pm \\
0.10^{* *}\end{array}$ & $\begin{array}{l}1.99 \pm \\
0.11 \\
\end{array}$ \\
\hline$\%$ of change & & $72 \%$ & $9 \%$ \\
\hline
\end{tabular}

Values represent mean \pm SE (standard error). ( $\mathrm{P}^{*<}$ $0.05, \mathrm{P}^{* *}<0.01$ as compared to control group).

\section{Kidney functions:}

There was an obvious increase in the levels of creatinine and urea in rats, which treated with the mixture of food additives ( $p<0.01)$. While, VIT.C caused no significant change in the previous parameters as compared to control rats (Table 5).
Table (5): Serum creatinine and urea levels in control, Mixture (Sodium Benzoate+ Mono Sodium glutamate + Chlorophyllin)- and (Mixture+ Vitamin C)-treated animals.

\begin{tabular}{|l|l|l|l|}
\hline Groups & Control & Mixture & $\begin{array}{l}\text { Mixture } \\
\text { +Vitamin } \\
\text { C }\end{array}$ \\
\hline Creatinine(mg/l) & $\begin{array}{l}0.91 \pm \\
0.11\end{array}$ & $\begin{array}{l}1.30 \pm \\
0.07 *\end{array}$ & $\begin{array}{l}1.15 \pm \\
0.10\end{array}$ \\
\hline $\begin{array}{l}\text { \%of change from } \\
\text { control }\end{array}$ & & $43 \%$ & $26 \%$ \\
\hline Urea(mg/dl) & $\begin{array}{l}30.34 \pm \\
1.98\end{array}$ & $\begin{array}{l}41.45 \pm \\
1.08 * *\end{array}$ & $\begin{array}{l}34.52 \pm \\
1.65\end{array}$ \\
\hline $\begin{array}{l}\text { \%of change from } \\
\text { control }\end{array}$ & & $37 \%$ & $14 \%$ \\
\hline
\end{tabular}

Values represent mean \pm SE (standard error). $\left(\mathrm{P}^{*}<0.05\right.$, $\mathrm{P}^{* *}<0.01$ as compared to control group).

\section{Hormones:}

T3 and T4 levels revealed insignificant change in all treated group with regard to the control rats. Meanwhile, there was a highly significant decline ( $\mathrm{p}<$ 0.01 ) in testosterone level in the group received food additives, while there was no significant change in the group that received VIT.C in comparison with the control (Table 6).

Table (6): Serum Testosterone, T3 and T4 levels in control, Mixture (Sodium Benzoate+ Mono Sodium glutamate + Chlorophyllin)- and (Mixture +Vitamin C)-treated animals

\begin{tabular}{|l|l|l|l|}
\hline Groups & Control & Mixture & $\begin{array}{l}\text { Mixture } \\
+ \text { Vitamin C }\end{array}$ \\
\hline Testosterone(ng/dl) & $\begin{array}{l}57.30 \pm \\
2.14\end{array}$ & $\begin{array}{l}44.06 \pm \\
1.85 * *\end{array}$ & $\begin{array}{l}53.42 \pm \\
1.56\end{array}$ \\
\hline $\begin{array}{l}\text { \%of change from } \\
\text { control }\end{array}$ & & $-23 \%$ & $-7 \%$ \\
\hline T3(ng/dl) & $\begin{array}{l}108.22 \pm \\
2.27\end{array}$ & $\begin{array}{l}113.27 \\
\pm 0.88\end{array}$ & $\begin{array}{l}111.64 \pm \\
1.89\end{array}$ \\
\hline $\begin{array}{l}\text { \%of change from } \\
\text { control }\end{array}$ & & $5 \%$ & $3 \%$ \\
\hline $\begin{array}{l}\text { T4(ng/dl) } \\
\begin{array}{l}\text { \%of change from } \\
\text { control= }\end{array}\end{array}$ & $4.57 \pm 0.45$ & $\begin{array}{l}5.24 \pm \\
0.14\end{array}$ & $4.92 \pm 0.10$ \\
\hline
\end{tabular}

Values represent mean $\pm \mathrm{SE}$ (standard error). ( $\mathrm{P}^{*}<$ $0.05, \mathrm{P}^{* *}<0.01$ as compared to control group.

\section{DISCUSSION}

Food additives are substances that are part of a food product, which are added (intentionally or unintentionally) during the processing or production of food. They include salt to preserve meats, herbs or spices that are added to foods, or pickling foods in 
vinegar solutions. However, food additives most often relate to artificial ingredients added to food ${ }^{(11)}$.

As it is illustrated in the results, there was insignificant change in the body weight in the treated animals with mixture of food additives (MSG, SB and CHL) in contrast to control rats. There may be antagonistic effect occur between CHL (which reduced the body weight) and MSG (which cause obesity) to balance the both effects of the two food additives to be close to the body weight value of control rats. Cekic et al. ${ }^{(\mathbf{1 2})}$ found that obesity induced after administration of MSG in newborn mice was of rapid onset due to lesions in hypothalamic arcuate nucleus and impaired leptin and insulin signaling in this region. Leptin is an appetite-suppressing hormone that regulates energy and controls appetite and body weight. In MSG-treated rats much adipose tissue was located mainly within the greater omentum and behind the peritoneum. Chlorophyllin group recorded a highly significant decrease in body weight. Similar finding was also recorded in Helal et al. ${ }^{(13)}$ who stated that synthetic food colorants cause a reduction in body weight.

Our results showed a highly significant elevation in fasting blood glucose level, insulin value and HOMA-IR ratio in rats orally administrated with mixtures. The elevation of glucose level can be explained by stimulation of glycogenolysis and gluconeogenesis by the liver with temporary loss of endocrine functions of pancreas leading to hyperglycemia. The increased blood glucose level following MSG administration was attributed to increased gluconeogenesis from glutamate and glutamine. The abnormal glucose tolerance could be attributed to decreased cellular insulin sensitivity even under conditions of hyperinsulinemia observed in animals treated with MSG. Under conditions of hyperinsulinemia, cells could switch to pathways that favor gluconeogenesis to compensate for the increased insulin release ${ }^{(14)}$.

Brice et al. ${ }^{(15)}$ showed that the increases in insulin level could be attributed to the presence of glutamate receptors in $\beta$ pancreatic cell. They found that endogenous activation of mGlu5 receptors (glutamate receptor) was permissive to glucosestimulated intracellular $\mathrm{Ca}$ release and insulin secretion. Mice lacking mGlu5 receptors or treated with a selective mGlu5 receptor antagonist showed blunted insulin response to glucose.

The presence of hyperinsulinemia/ hyperglycemia in MSG-treated rats because glutamate did not lower blood glucose level despite the rise in insulin secretion to a very high value. Afra et al. ${ }^{(16)}$ suggested that glutamate caused insulin resistance because during the compensated phase on insulin resistance, insulin levels are higher, and blood glucose levels are still maintained. Insulin itself leads to a kind of insulin resistance. Higher level of insulin than usual can lead to a kind of positive feedback, increases the need for insulin and causes down regulation of Glut4 receptor. Insulin resistance in glutamate-treated group could also be due to changes in insulin binding or postreceptor insulin effects in target tissues . Sodium benzoate may play a role in enhancing pancreatic secretions, glycogen metabolism or gluconeogenesis, and hence glucose mobilization to the blood ${ }^{(17)}$.

Vitamin C improve the condition of diabetes mellitus in mixture-treated rats that was indicated by parameters like serum glucose level, insulin level and HOMA-IR. This action is possibly due to regeneration of $\beta$-cells and improving insulin sensitivity which lower the concentration of glucose in blood by inhibiting hepatic glucose production and by stimulating glucose uptake and metabolism by muscle and adipose tissues, which explain the lowering of the glucose level and increasing liver glycogen content ${ }^{(\mathbf{1 8})}$. These results are in agreement with Hamden et al. ${ }^{(19)}$ who found that combined vitamins (C and E) can be effective in inhibiting hyperglycemia, oxidative stress and cell damage in pancreas and liver, by enhancing antioxidant enzyme activity, scavenging ROS and eventually by contributing to the improvement of tissue dysfunction in diabetic rats.

A highly significant decrease in total protein, albumin, and globulin as compared to control rats. In mixture group, these reductions may be due to oxidative stress, which affects liver (the main site for protein synthesis in the body). Thus, the synthetic function of liver was altered by MSG and / or SB indicating liver damage arising from the uptake of the chemical compound. This might be an indication of diminished synthetic function of the liver, which may consequently lead to enhanced retention of fluid in the tissue spaces. In addition, MSG stimulates thyroid and adrenal glands, which lead to a blocked protein synthesis, fast breakdown increased and decreased protein turnover ${ }^{(20)}$. Additionally, V.C resulted in a significant improvement in the serum total protein level. Vitamin has the ability to prevent oxidative stress, which affects liver, the main site for protein synthesis in the body ${ }^{(21)}$.

Our study demonstrated that liver activities (ASAT and ALAT) showed a highly significant increase in food additives-treated rats in comparison with the control group. Liver enzymes activities were used as important biomarkers for detection of hepatotoxicity. The liver is the most sensitive organ to pre-oxidative damage because it is rich in oxidizable substances. The more severe the liver damage the higher release of the liver enzymes. Increase in serum level of ALAT and ASAT as observed in groups induced with these additives might reflect damage of liver cells and cellular degeneration or destruction, which might be due to the increased permeability of 
plasma membrane or cellular necrosis. When the liver cell membrane is damaged, varieties of enzymes normally located in the cytosol are released into the blood stream. Elevation of ASAT and ALAT indicates the utilization of amino acids for the oxidation or for gluconeogenesis. They are used to determine liver damage and cell necrosis due to toxicity ${ }^{(22)}$.

There are observed elevation in the activities of serum enzymes aspartate aminotransferase, alanine aminotransferase and alkaline phosphatase in response to sodium benzoate. Aziz and Zabut ${ }^{(\mathbf{1 7})}$ reported that activities of alanine aminotransferase and aspartate aminotransferase are a common sign of impaired liver function.

When the animals treated with VIT C, ASAT and ALAT elevation was reduced to a value close to the normal. This may be due to the antioxidant activity of vitamin c. This protective effect of vitamin C against toxicity of MSG occurred because of its antioxidant action ${ }^{(23)}$. A previous study suggested that the ameliorating effects of vitamin $\mathrm{C}$ were to be likely mediated via inhibition of free radicals generation and/or free radical scavenging activity ${ }^{(24)}$.

In the current study, the results revealed significant increase in serum level of total cholesterol (TC), triglycerides (TG), low density lipoprotein cholesterol (LDL-c) and very low density lipoprotein cholesterol (VLDL-c) accompanied with a significant decrease in high density lipoprotein cholesterol (HDLc) level in mixture group as compared to control group. Our results are in agreement with Thomas et al. (25) who reported that there were an increase in the levels of cholesterol, triglycerides, and free fatty acids in plasma and tissues. MSG increases the synthesis of fatty acids and triglycerides from acetate. This could be due to the transport of acetate into the liver cell resulting in increased substrate (acetate) availability. MSG intake also increases the synthesis of cholesterol. Another reason, that monosodium glutamate was able to increase the activities of 3-hydroxyl-3 methylglutaryl coenzyme A (HMG Co A) reductase, the rate limiting enzyme in cholesterol biosynthesis, resulting in increased synthesis of cholesterol in the MSG-treated rats. Thomas et al. (25) reported hyperlipidemia with significantly elevated levels of serum triacylglycerol and cholesterol in monosodium glutamate-treated rats and proposed that a shift in glucose metabolism towards lipogenesis might account for the hyperlipidemia.

The effect of sodium benzoate on lipid profile and their increasing effect in cholesterol concentration in the present study might be an indication of membrane structure and function disruption, thus influencing its fluidity, permeability, activity of associated enzymes and transport system ${ }^{(26)}$. Vitamin $\mathrm{C}$, a water-soluble antioxidant, acts as an important factor in lipid regulation, increases HDL levels and protects against LDL oxidation. Our findings showed a significant increase of HDL concentration significant decrease in, cholesterol, LDL, and triglyceride levels as well as reduction of LDL/HDL ratio when rats were treated with VIT.C ${ }^{(27)}$.

Our results demonstrated that the daily intake of MSG and SB exhibited an increase in serum urea and creatinine when compared to the normal control. Food preservatives caused changes in kidney convoluted tubules cells lining as well as in Bowman's corpuscles. There was an elevation in kidney functions parameters after administration of MSG that led to alterations in kidney functions. These impairments could also be attributed to the changes in the threshold of tubular reabsorption, renal blood flow and glomerular filtration rate (GFR) ${ }^{(22)}$.

Addition of V.C resulted in a significant improvement in serum levels of biochemical parameters in kidneys. Tawfik and Al-Badr (21) recorded that dietary antioxidants such as Vitamin $\mathrm{C}$ and Vitamin $\mathrm{E}$ had a modulator effects on MSGinduced serum urea oxidative damage in the liver and kidney of rats. The variation in the level of urea and creatinine are markers of renal dysfunction.

As it is explained in the previous results, there was a highly significant decrease in the mixturetreated animals in testosterone level. Food additives reduced androgens, which indirectly affect the axis connecting the pituitary gland. This had negative effects on social behavior and the relative weight of members of the sex-producing hormone. MSG caused reduction in testosterone hormone as it obstructed the hypothalamic-pituitary-testes regulatory axis that controls testosterone production by testicular Leydig cells ${ }^{(20)}$.

The results of this study showed significant reduction in testosterone in rats that were exposed to mixture. Kehinde et al. ${ }^{(4)}$ reported a reduction in FSH, $\mathrm{LH}$ and testosterone in rats that were exposed to SB, which is consistent with previous observations. The possibility of the low levels of plasma FSH and LH concentration following SB exposure might be due to increased oxidative stress. Oxidative stress may suppress the sensitivity of the gonadotrophic cells to gonadotropin-releasing hormone. Therefore, may prevent gonadotropin secretion. In addition inhibition of FSH and LH by SB might be a result of its negative effect on central nervous system that can inhibit the neural stimulus essential for the release of pituitary gonadotrophins leading to a lack of pituitary gonadotrophins essential for initiating and completing spermatogenesis and steroidogenesis in the testis ${ }^{(27)}$.

Meanwhile, VIT. C recorded a significant improvement in the value of testosterone hormone and elevated its level as compared to the mixture-treated animals. Biswas et al. ${ }^{(28)}$ reported that ascorbic acid stimulated testicular steroid dehydrogenase activity 
and increased plasma testosterone level. Karanth $\boldsymbol{e t}$ al. ${ }^{(29)}$ reported that ascorbic acid is a vitaminergic transmitter that activates the release of both FSH and LH from the anterior pituitary gland by autocrine action by means of nitric oxide. LH causes the release of testosterone from Leydig cells . Sönmez et al. ${ }^{(30)}$ illustrated that plasma testosterone level significantly increased in the ascorbic acid treated animals when compared to control animals. This increase might be because ascorbic acid activates release of the LH .

The current investigation demonstrated that the daily intake of SB, CHL and monosodium glutamate exhibited insignificant change in thyroid hormones $\mathrm{T} 3$ and $\mathrm{T} 4$ that might be resulting from antagonestic effect between $\mathrm{SB}$ (which reduces thyroid hormones T3 and T4) and MSG (which causes increase thyroid hormones $\mathrm{T} 3$ and $\mathrm{T} 4$ ) to balance the effects of the two food additives. Thus, T3 and T4 become close to value of control rats.

Finally, it was concluded that food additives have extreme destructive effects on most physiological parameters like liver and kidney enzymes, testosterone hormone and lipid and protein profiles. Therefore, we should minimize their use in most foods especially for kids. In addition, we recommend using of VIT $\mathrm{C}$ as it achieved excellent therapeutic effects against the disturbances that occurred to animals due to food additives administration and returned these abnormalities to around the normal values.

\section{REFERENCES}

1. Afeefy A, Mahmoud M, Arafa M (2012): Effect of honey on monosodium glutamate induced nephrotoxicity (histological and electron microscopic studies). Journal of American Science, 8 (1s): 146-156.

2. Leite SV, Oliveira R J, Nakamura Kanno T Y et al. (2013): Chlorophyllin in the intra-uterine development of mice exposed or not to cyclophosphamide. Acta Scientiarum Health Sciences, 35 (2): 201-210.

3. Oyewole OI, Dere F A, Okoro OE (2012): Sodium benzoate mediated hepatorenal toxicity in wistar rat: Modulatory effects of azadirachtaindica (neem) leaf. European Journal of Medicinal Plants, 2 (1): 11-18.

4. Kehinde OS, Christianah O I, Oyetunji OA (2018): Ascorbic acid and sodium benzoate synergistically aggravates testicular dysfunction in adult Wistar rats. International Journal of Physiology, Pathophysiology and Pharmacology, 10 (1): 39-46.

5. Buxton DW (1888): The use of anesthetics. The Lancet, 132 (3401): 888-889.

6. Young DS (2001): Effects of disease on Clinical Lab. Tests. 4th ed. AACC. WB Saunders Company, Philadelphia, Pp: 147 - 148.

7. Friedewald WT, Levy RI, Fredrickson DS (1972): Estimation of the concentration of low-density lipoprotein cholesterol in plasma, without use of the preparative ultracentrifuge. Clin. Chem., 18: 499-502.

8. Norbert WT (1995): Clinical guide to laboratory tests. 3rd ed. Saunders W. B., Company, Philadelphia. https://onlinelibrary.wiley.com/doi/abs/10.1111/j.15372995.1995.tb03571.x

9. Reeves WG (1983): Insulin antibody determination: Theoretical and practical consideration. Diabetologia, 24 (6): 399-403.

10. Matthews DR, Hosker JP, Rudenski AS, Treacher DF et al. (1985): Homeostasis model assessment: insulin resistance and beta cell function from fasting plasma glucose and insulin concentration in man. Diabetologia, 28 (7): 412-419.

11. Rangan C, Barceloux DJ (2009): Food additives and sensitivity. Dis. Mon., 55 (5): 292-311

12. Cekic S, Filipovic M, Pavlovic Vet al.(2005): Histopathologic changes at the hypothalamic, adrenal and thymic nucleus arcuatus in rats treated with Monosodium Glutamate. Acta Med Median , 44 (3): 3542.

13. Helal E G, Barayan A W, Abdelaziz M A, ELShenawe N S (2019): AdverseEffects of Two Kinds of Food Additive Mixtures (Sodium benzoate + Monosodium glutamate, Monosodium glutamate + Chlorophyllin and Sodium benzoate + Chlorophyllin) on Some Physiological Parameters in Male Albino Rats. Egyptian Journal of Hospital Medicine, 75 (4): 27362744.

14. Tawfek N, Amin H, Abdalla A, Fargali S (2015): Adverse effects of some food additives in adult male albino rats. Current Science International, 4 (4): 525537.

15. Brice N L, Varadi A, Ashcroft S J, Molnar E (2002): Metabotropic glutamate and GABA (B) receptors contribute to the modulation of glucose-stimulated insulin secretion in pancreatic beta cells. J. Diabetologia, 45 (2): 242-252.

16. Elshaikh A A F, Abuelgassim A I (2013): The Effect of Monosodium Glutamate in Plasma Insulin Glucose Levels in Wester Albino Rats.https://www.researchgate.net/publication/3258536 99

17. AzizI A, Zabut B M (2012): Blood indices of sodiumbenzoate-administrated albino rats: effect of olive oil and/or time-dependent recovery. Egyptian Journal of Biology, 14: 50-56.

18. Helal E G, Abd-Elwahab S M,Mohammad A A (2013): Comparison between the effect of ozone and vitamin $\mathrm{C}$ in treatment of diabetes mellitus. The Egyptian Journal of Hospital Medicine, 31 (762): 1-14.

19. Hamden K, Boujbiha MA, Masmoudi H et al. (2009): Dossier: Redox balance in human pathologies combined vita-mins ( $\mathrm{C}$ and $\mathrm{E}$ ) and insulin improve oxidative stress and pancreatic and hepatic injury in alloxan diabetic rats. Biomedicine, Pharmacotherapy, 63: 95-99.

20. Helal EG, El-Sayed R A, Mustafa M A, El-Gamal M S (2017): Adverse effects of two kinds of food additive mixtures (flavor enhancer, food preservative or food coloring agent) on physiological parameters in young male albino rats. The Egyptian Journal of Hospital Medicine, 31 (71): 1-8

21. Tawfik M S, Al-Badr N (2012): Adverse effects of monosodium glutamate on liver and kidney functions in adult rats and potential protective effect of vitamins $\mathrm{C}$ and E. Food and Nutrition Sciences, 3 (05): 651-659. 
22. Ahmed M (2016): Effect of some Food Additives Consumption on the Body Weight and Toxicity and the Possible Ameliorative Role of Green Tea Extract. Sciences, 6 (04): 716-730.

23. Dosuky MA, Zaghlol DA, Ouies SM et al. (2018): Effects of Monosodium Glutamate on the Liver of Male Adult Albino Rat and the Possible Protective Role of Vitamin C (Light and Electron Microscopic Study Med. J. Cairo Univ., 86 (7): 3407-3418.

24. Barja G, Lopez Torres M, Perez-Campo $R$ et al. (1994): Dietary vitamin c decreases endogenous protein oxidative damage, malondialdehyde, and lipid peroxidation and maintains fatty acid unsaturation in the guinea pig liver. Free Radicals Biology and Medicine, 17 (2): 105-115.

25. Thomas M, Sujatha KS, George S (2009): Protective effect of Piper longum Linnonmonosodium glutamate induced oxidative stress in rats. Indian J. Exp. Biol., 47 (3): 186-92.

26.Sarhan M A, Shati A A, Elsaid F G (2014): Biochemical and molecular studies on the possible influence of the Brassica oleracea and Beta vulgaris extracts to mitigate the effect of food preservatives and food chemical colorants on albino rats. Saudi Journal of Biological Sciences, 21 (4): 342-354.

27.El Mashad G M, ElSayed H M, Nosair N A (2016): Effect of vitamin $\mathrm{C}$ supplementation on lipid profile, serum uric acid, and ascorbic acid in children on hemodialysis. Saudi Journal of Kidney Diseases and Transplantation, 27 (6): 1148-1154.

28. Biswas N M, Chaudhuri A, Sarkar M et al. (1996): Effect of ascorbic acid on in vitro synthesis of testosterone in rat testis. Indian Journal of Experimental Biology, 34 (6): 612-613.

29. Karanth S, Wen H Y, Walczewska A et al.(2001): Ascorbic acid stimulates gonadotropin release by autocrine action by means of NO. Proceedings of the National Academy of Sciences, 98 (20): 11783-11788.

30.Sönmez M, Türk G, Yüce A (2005): The effect of ascorbic acid supplementation on sperm quality, lipid peroxidation and testosterone levels of male Wistar rats. Theriogenology, 63 (7): 2063-2072. 